\title{
ANALISIS TRANSFORMASI INDEKS NDVI, NDWI DAN SAVI UNTUK IDENTIFIKASI KERAPATAN VEGETASI MANGROVE MENGGUNAKAN CITRA SENTINEL DI PESISIR TIMUR PROVINSI LAMPUNG
}

\author{
Nirmawana Simarmata ${ }^{1,2}$, Ketut Wikantika ${ }^{3}$, Trika Agnestasia Tarigan ${ }^{2,4}$, \\ Muhammad Aldyansyah ${ }^{4}$, Rizki Kurnia Tohir ${ }^{2,4}$, Afi Fauziah ${ }^{1}$, Yustika Purnama ${ }^{2}$ \\ ${ }^{1}$ Teknik Geomatika, Institut Teknologi Sumatera \\ ${ }^{2}$ Pusat Riset dan Inovasi Sains Informasi Geospasial, Institut Teknologi Sumatera \\ ${ }^{3}$ Teknik Geodesi dan Geomatika, Institut Teknologi Bandung. \\ ${ }^{4}$ Teknik Kelautan, Institut Teknologi Sumatera \\ ${ }^{5}$ Rekayasa Kehutanan, Institut Teknologi Sumatera
}

\begin{abstract}
Abstrak: Perolehan informasi keberadaan hutan mangrove yang memiliki potensi, peran dan fungsi besar dalam kehidupan, dapat diperoleh melalui data penginderaan jauh. Teknologi penginderaan jauh memiliki efisien tinggi dan banyak kelebihan untuk keperluan monitoring hutan mangrove. Penelitian ini bertujuan untuk mengidentifikasi kerapatan ekosistem mangrove dengan menggunakan transformasi indeks vegetasi serta menguji efektivitas beberapa indeks vegetasi dalam hal ini NDVI, NDWI dan SAVI untuk identifikasi jenis dan kerapatan mengrove. Berdasarkan hasil analisis citra Sentinel dengan menggunakan transformasi indeks NDVI, SAVI, dan NDWI untuk identifikasi kerapatan vegetasi pada transformasi NDVI didominasi kelas kerapatan tinggi yaitu pada rentang nilai $0,67-1$ yaitu seluas 46975,96 Ha, pada transformasi SAVI didominasi kelas kerapatan sangat jarang yaitu pada rentang nilai 0,99 - 1,38 yaitu seluas 48775,18 Ha, pada transformasi NDWI didominasi kelas kerapatan rendah yaitu pada rentang nilai 0,1 - 0,17 yaitu seluas 27442,26 Ha. Hasil uji akurasi yang dilakukan menggunakan 30 sampel uji diperoleh akurasi sebesar 83,33\%.
\end{abstract}

Kata kunci: mangrove, Sentinel, NDVI, NDWI, SAVI

Abstract : Obtaining information on the existence of mangrove forest which have great potential, role and fuction in live, can be obtained through remote sensing data. Remote sensing technology has high efficiency and many advantages for monitoring mangrove forest. This study aims to identify the density of the mangrove ecosystem by using the transformation of the vegetation index and to test several vegetation indices in this case NDVI, NDWI and SAVI in terms of effectiveness in identifying types and densities of mangroves. Based on the results of Sentinel image analysis using the NDVI, SAVI, and NDWI index transformations to identify vegetation density in the NDVI transformation, the high density class is dominated by the high density class, which is in the range of values $0.67-1$, which is $46975.96 \mathrm{Ha}$, the SAVI transformation is dominated by the very rare density class. namely in the range of values $0.99-1.38$, which is $48775.18 \mathrm{Ha}$, the NDWI transformation is dominated by low density classes, namely in the range of values $0.1-0.17$, which is 27442.26 Ha. Based on the results of the accuracy test conducted using 30 test samples, an accuracy of $83.33 \%$ was obtained.

Keywords: mangrove, Sentinel, NDVI, NDWI, SAVI

\section{A. PENDAHULUAN}

Menurut Menteri Lingkungan

Hidup dan Kehutanan, pada Konferensi

Internasional Ekosistem Mangrove
Berkelanjutan di Bali pada 18 April 2017, Indonesia merupakan negara dengan potensi mangrove terluas di dunia karena termasuk negara kepulauan yang

Corespondency address : 
mana terdapat 3,5 juta hektar ekosistem mangrove yang terdiri dari 2,2 juta hektar di dalam kawasan dan 1,3 juta hektar di luar Kawasan mangrove (http://ksdae.menlhk.go.id/).

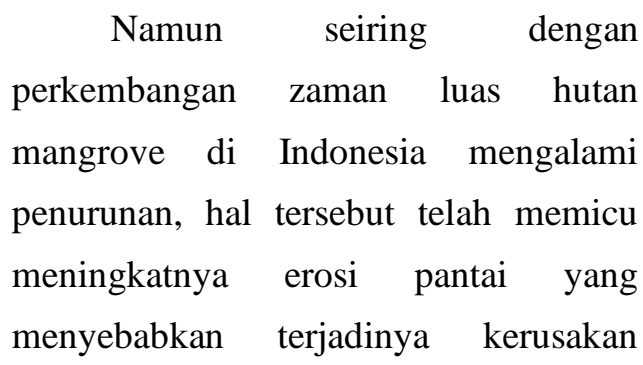
habitat alami, punahnya berbagai jenis flora fauna dan biota tertentu, serta menurunnya keanekaragaman hayati. Kerusakan tersebut disebabkan oleh perubahan penggunaan lahan, perambahan, hama dan penyakit, pencemaran dan perluasan tambak, serta praktik budidaya yang tidak berkelanjutan

(http://ksdae.menlhk.go.id).

Identifikasi obyek dengan menggunakan teknologi penginderaan jauh dilaksanakan dengan beberapa pendekatan antara lain; karakteristik spektral citra, visualisasi, floristik, geografi dan phsygonomik (Hartono, 1998), khususnya pada sistem satelit (citra satelit) lebih banyak didasarkan atas karakteristik spektral. Obyek yang berbeda akan memberikan pantulan spektral yang berbeda pula, bahkan obyek yang sama dengan kondisi dan kerapatan yang berbeda akan memberikan nilai spektral yang berbeda. (swain, 1978).

Ekosistem mangrove merupakan salah satu obyek yang bisa diindentifikasi dengan menggunakan teknologi penginderaan jauh. Letak geografi ekosistem mangrove yang berada pada daerah peralihan darat dan laut memberikan efek perekaman yang khas jika dibandingkan obyek vegetasi darat lainnya. Efek perekaman tersebut sangat erat kaitannya dengan karakteristik spektral ekosistem mangrove, hingga dalam identifikasi memerlukan suatu transformasi tersendiri (Kustandiyo, 2004).

Mengingat pentingnya hutan mangrove maka perlu dilakukan pengelolaan yang tepat sehingga dapat tercapai pemanfaatan yang lestari. Untuk mendukung pengelolaan hutan mangrove dibutuhkan data dan informasi spasial mengenai gambaran wilayah hutan mangrove yang update (Riwayati, 2014).

Pada umumnya untuk deteksi vegetasi digunakan transformasi indeks vegetasi (Danoedoro, 1996). Indeks vegetasi merupakan suatu algoritma yang diterapkan terhadap citra satelit, untuk menonjolkan aspek kerapatan vegetasi ataupun aspek lain yang berkaitan dengan kerapatan, misalnya biomassa, Leaf Area Index (LAI), konsentrasi klorofil. 


$\begin{array}{ll}\text { Berdasarkan atas fenomena } & \text { efektifitas dalam identifikasi jenis dan } \\ \text { tersebut maka perlu dilakukan } & \text { kerapatan mangrove. } \\ \text { pengkajian tentang identifikasi jenis dan } & \text { B. METODE } \\ \text { kerapatan ekosistem mangrove dengan } & \text { Lokasi penelitian dilaksanakan di } \\ \text { menggunakan transformasi indeks } & \text { sepanjang pantai Lampung Timur hingga } \\ \text { vegetasi serta menguji beberapa indeks } & \text { Lampung Selatan. Data yang digunakan } \\ \text { vegetasi dalam hal ini yaitu Normalized } & \text { pada saat penelitian ini dilakukan yaitu } \\ \text { Difference Vegetation Index (NDVI), } & \text { citra satelit Sentinel-2A tahun 2019 } \\ \text { Normalized Difference Water } & \text { dengan menggunakan band } 4 \text { (red) dan } \\ \text { Index (NDWI) dan Soil Adjusted } & \text { band } 8 \text { (NIR). }\end{array}$

Vegetation Index (SAVI) dalam hal

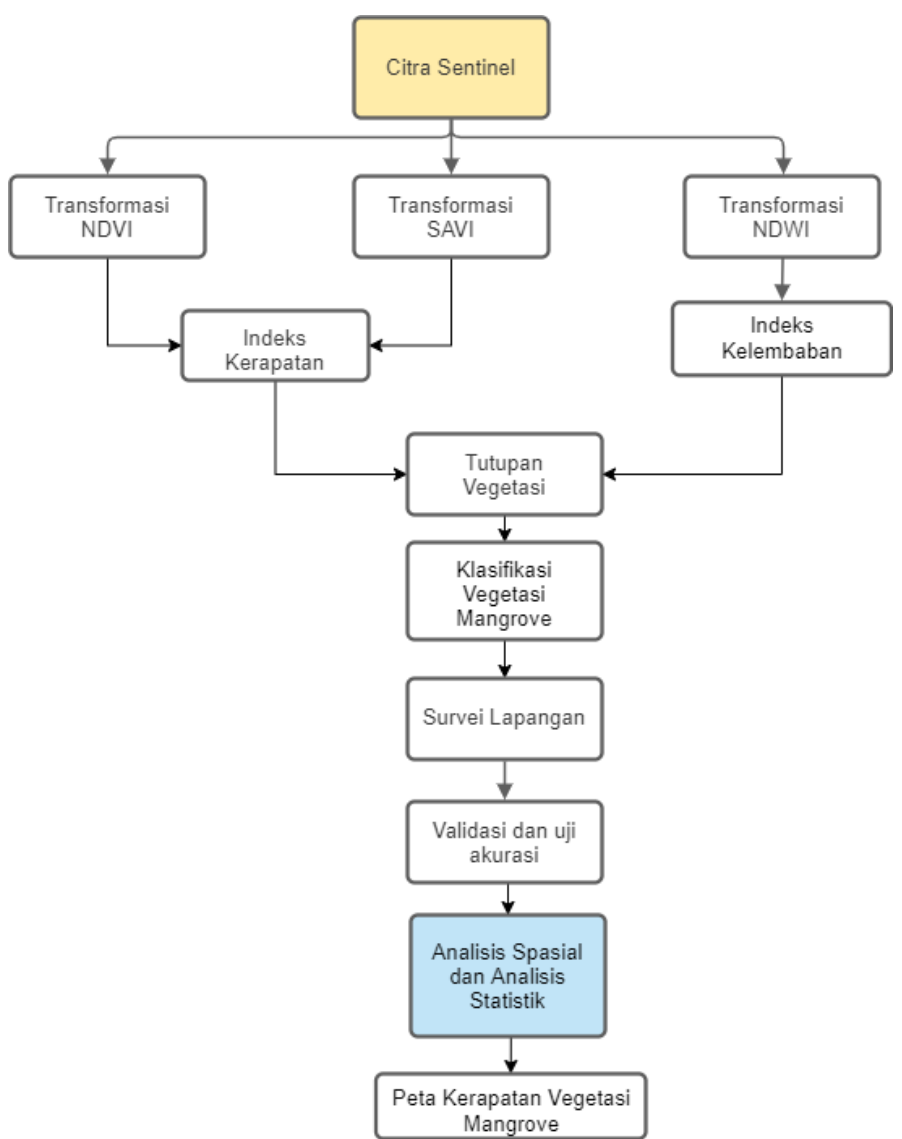

Gambar 1. Diagram alir penelitian

Tahap pertama dari penelitian ini yaitu mencari metode yang akan digunakan, mempersiapkan studi literatur, serta pengumpulan data. Pada tahap studi literatur yaitu mencari referensi-refernsi dari penelitian yang telah dilakukan sebelumnya yang berhubungan dengan penelitian yang akan dilakukan. Pengolahan dilakukan menggunakan software ArcGIS 10.6 
dengan mengkelaskan masing-masing klasifikasi yang telah dibuat sebelumnya. Setelah didapatkan hasil pengkelasan dilakukan validasi data lapangan untuk selanjutnya dilakukan uji akurasi. Lebih jelasnya, diagram alir penelitian dijelaskan pada Gambar 1.

Normalized Difference Vegetation Index (NDVI) merupakan perhitungan citra yang digunakan untuk mengetahui tingkat kehijauan vegetasi. NDVI dapat menunjukan parameter yang berhubungan dengan vegetasi, antara lain: biomassa dedaunan hijau, daerah dedaunan hijau yang merupakan nilai yang dapat diperkirakan untuk pembagian vegetasi. Indeks memberikan angka antara -1 dan 1 yang mewakili kepadatan tutupan vegetasi. Secara umum indeks mendekati 1, artinya vegetasi lebat dan kurang dari nol merepresentasikan air dan awan.

Algoritma dalam aplikasi penginderaan jauh untuk mengukur tingkat kehijauan vegetasi dengan memanfaatkan gelombang inframerah dekat dan gelombang merah (Putri, Sukmono dan Sudarsono, 2018). Berikut merupakan persamaan NDVI:

$$
\mathrm{NDVI}=\frac{(\mathrm{NIR}-\mathrm{Red})}{(\mathrm{NIR}+\mathrm{Red})}
$$

Keterangan:

NDVI = Normalized Difference

Vegetation Index

$$
\begin{aligned}
& \text { NIR }=\text { Band Near Infrared }(\text { Band } 4) \\
& \text { Red }=\text { Band Red }(\text { Band } 3)
\end{aligned}
$$

Normalized Difference Water

Index (NDWI) merupakan metode yang digunakan untuk membandingkan tingkat kebasahan pada citra satelit. Metode NDWI menggunakan band 8 (NIR) dan band 8 (SWIR). NDWI dirumuskan seperti pada persamaan (2) (Gao, 1996 dalam Wiweka, dkk., 2014):

$$
\mathrm{NDWI}=\frac{(\mathrm{NIR}-\mathrm{SWIR})}{(\mathrm{NIR}+\mathrm{SWIR})}
$$

Keterangan:

$$
\begin{array}{ll}
\text { NDWI } & =\text { Normalized Difference } \\
& \text { Water Index } \\
\text { NIR } & =\text { Band Near Infrared (Band 4) } \\
\text { SWIR } & =\text { Band Shortwave Infrared } \\
& \text { (Band 8) }
\end{array}
$$

Soil Adjusted Vegetation Index (SAVI) merupakan algoritma pengembangan dari NDVI dengan menekan pengaruh latar belakang tanah pada tingkat kecerahan kanopi. Metode SAVI menggunakan band 4 (NIR) dan band 8 (Red). SAVI dirumuskan pada persamaan (3).

$$
\mathrm{SAVI}=(1+\mathrm{L}) \mathrm{X} \frac{(\mathrm{NIR}-\mathrm{RED})}{(\mathrm{NIR}+\mathrm{RED})} .
$$

Keterangan:

SAVI $=$ Soil-Adjusted Vegetation Index

$\mathrm{NIR}=$ Band Near Infrared $($ Band 4$)$

RED = Band Shortwave Infrared

$$
\text { (Band 8) }
$$

$\mathrm{L}=$ Pencerahan Latar Belakang

Tanah $(0,5)$ 


\section{HASIL DAN PEMBAHASAN C.1. HASIL}

Hasil pengolahan citra Sentinel untuk identifikasi kerapatan vegetasi menggunakan transformasi NDVI diperoleh seperti Tabel 1 . Nilai min $-0,99$ yaitu kelas tidak ada vegetasi dan max 1 pada kelas kerapatan vegetasi tinggi.

Tabel 1. kelas kerapatan mangrove berdasarkan NDVI

\begin{tabular}{ccc}
\hline No & Klasifikasi Nilai NDVI & Kisaran Kerapatan \\
\hline $\mathbf{1}$ & $-0,99-0,1$ & Tidak Ada Vegetasi \\
\hline $\mathbf{2}$ & $0,1-0,24$ & Rendah \\
\hline $\mathbf{3}$ & $0,24-0,38$ & Agak Rendah \\
\hline $\mathbf{4}$ & $0,38-0,53$ & Sedang \\
\hline $\mathbf{5}$ & $0,53-0,67$ & Agak Tinggi \\
\hline $\mathbf{6}$ & $0,67-1$ & Tinggi \\
\hline
\end{tabular}

Sumber: hasil pengolahan (2020)

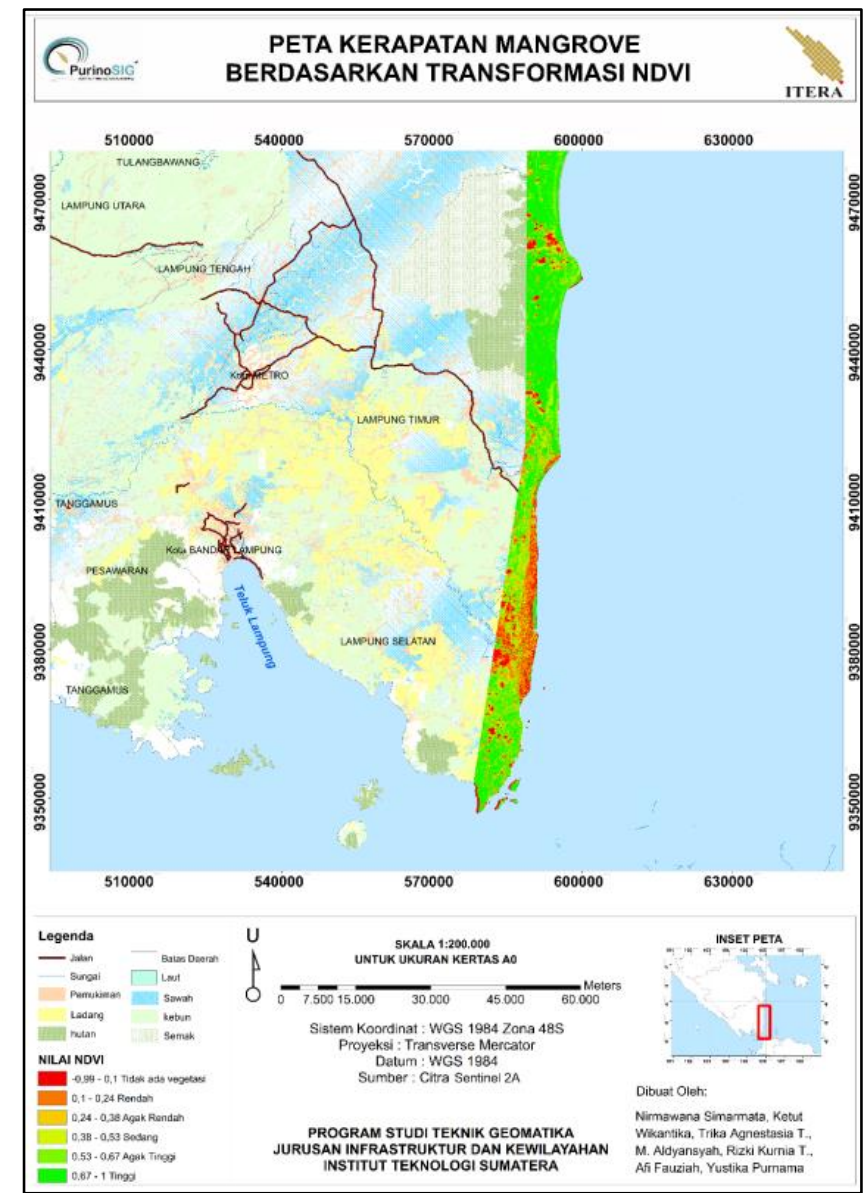

Gambar 2. Peta kerapatan mangrove hasil indeks NDVI

Gambar 2 menunjukkan peta daerah pantai timur Provinsi Lampung kerapatan mangrove berdasarkan didominasi oleh vegetasi mangrove transformasi NDVI didapatkan bahwa dengan kerapatan tinggi, hal itu dapat 
dilihat dari peta yang mana didominasi

identifikasi kerapatan vegetasi oleh warna hijau dengan nilai indeks menggunakan transformasi SAVI sebesar 0,67-1 yang artinya daerah diperoleh kerapatan vegetasi mangrove dengan kerapatan tinggi. Berdasarkan seperti Tabel 2.

hasil pengolahan citra Sentinel untuk

Tabel 2. kelas kerapatan mangrove berdasarkan SAVI

\begin{tabular}{ccc}
\hline No & Klasifikasi Nilai SAVI & Kisaran Kerapatan \\
\hline $\mathbf{1}$ & $-1--0,29$ & Tidak ada Vegetasi \\
\hline $\mathbf{2}$ & $-0,29-0,26$ & Rendah \\
\hline $\mathbf{3}$ & $0,26-0,66$ & Sedang \\
\hline $\mathbf{4}$ & $0,66-0,99$ & Tinggi \\
\hline $\mathbf{5}$ & $0,99-1,38$ & Sangat Tinggi \\
\hline & & Sumber: hasil pengolahan $(2020)$
\end{tabular}

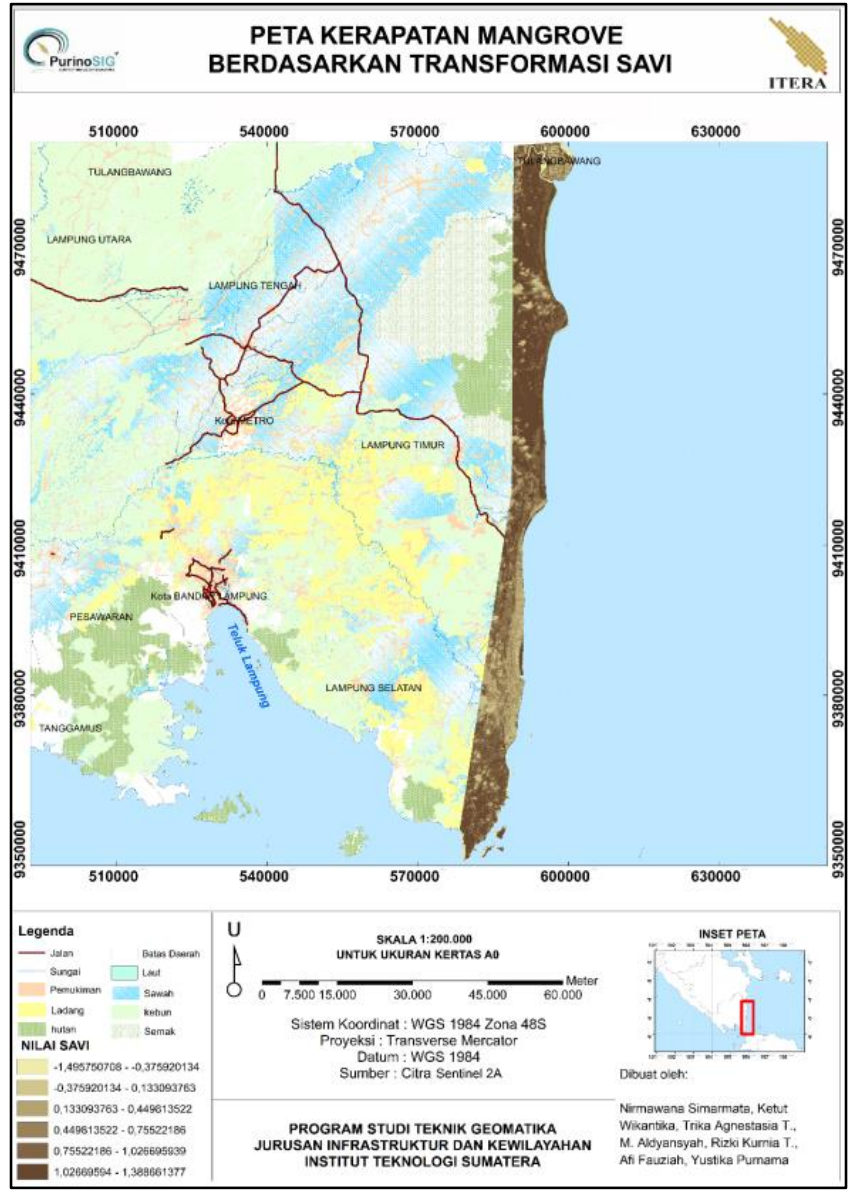

Gambar 3. Peta kerapatan mangrove hasil indeks SAVI

Pada indeks SAVI seperti pada Gambar 3, didapatkan bahwa daerah timur provinsi Lampung didominasi dengan hutan mangrove kerapatan sangat 
jarang dibeberapa daerah. Hal tersebut dapat dilihat dari hasil pengklasifikasian yang dilakukan menghasilkan nilai 0,991,38 yang artinya sangat tinggi. Hasil pengolahan citra Sentinel menggunakan transformasi NDWI ditunjukkan pada Tabel 3.

Tabel 3. kelas kerapatan mangrove berdasarkan NDWI

\begin{tabular}{ccc}
\hline No & Klasifikasi Nilai NDWI & Kisaran Kerapatan \\
\hline $\mathbf{1}$ & $-0,99-0,1$ & Tidak Ada Air \\
\hline $\mathbf{2}$ & $0,1-0,17$ & Rendah \\
\hline $\mathbf{3}$ & $0,24-0,27$ & Agak Rendah \\
\hline $\mathbf{4}$ & $0,27-0,37$ & Sedang \\
\hline $\mathbf{5}$ & $0,37-0,47$ & Tinggi \\
\hline $\mathbf{6}$ & $0,47-1$ & Sangat Tinggi \\
\hline
\end{tabular}

Sumber: hasil pengolahan (2020)

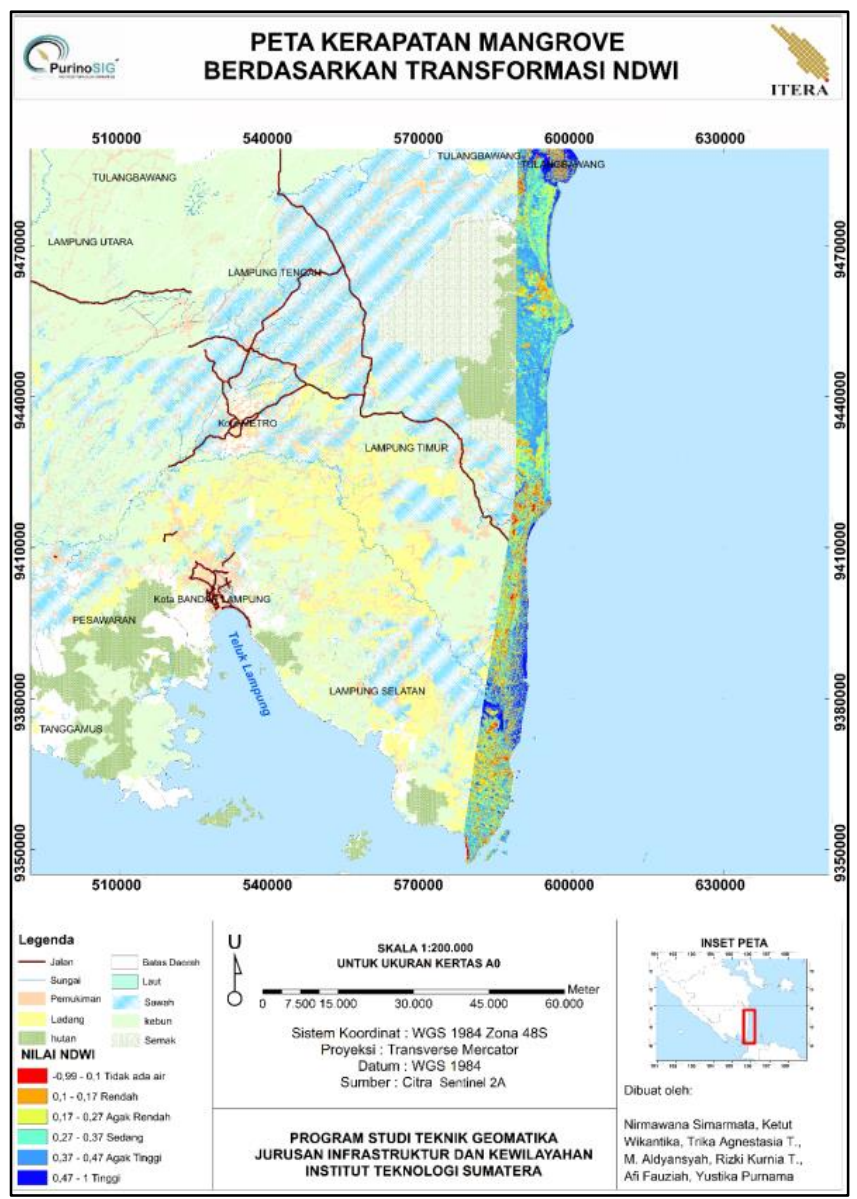

Gambar 4. Peta kerapatan mangrove hasil indeks NDWI

Berdasarkan transformasi NDWI seperti pada Gambar 4, didapatkan bahwa daerah pantai timur Provinsi Lampung memiliki kerapatan yang beragam menurut nilai kelembabannya. 


\section{C.2. PEMBAHASAN}

Penentuan indeks vegetasi mangrove dilakukan untuk mengetahui pola indeks vegetasi untuk kawasan hutan mangrove yang ada di Pantai Timur Provinsi Lampung. Nilai indeks NDVI provinsi lampung memiliki rentang nilai minimal antara $-0,99$ sampai nilai maksimal 1. Berdasarkan hasil analisis untuk objek mangrove memiliki rentang antara $0.1-1$. Nilai indeks dijadikan sebagai acuan untuk penentuan kerapatan hutan mangrove berdasarkan hasil transformasi algoritma NDVI. Berdasarkan hasil pengolahan citra Sentinel menggunakan algoritma NDVI. Gambar 5 merupakan hasil transformasi berdasarkan indeks NDVI.

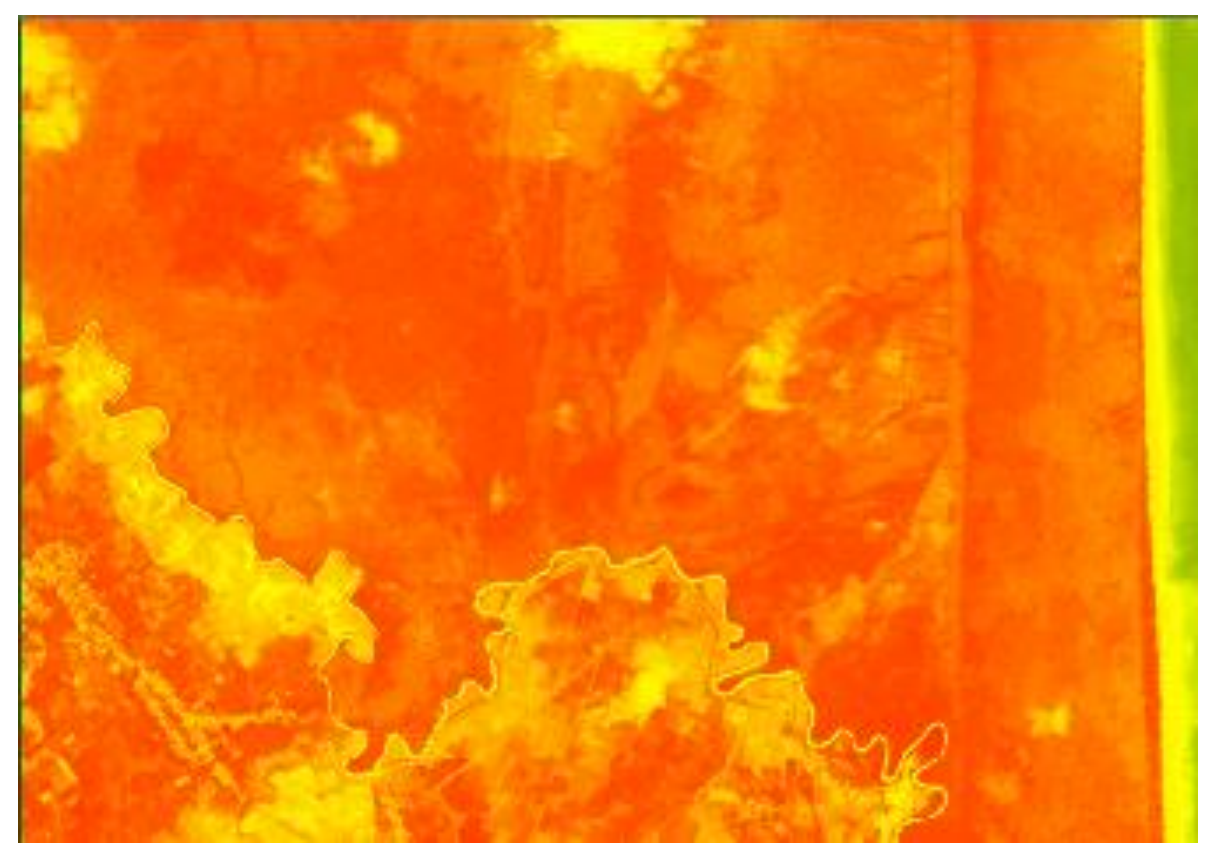

Gambar 5. tutupan mangrove berdasarkan NDVI

Analisis indeks vegetasi mangrove berdasarkan hasil transformasi menggunakan algoritma SAVI algoritma SAVI. Berdasarkan hasil dilakukan untuk mengetahui pola indeks vegetasi untuk kawasan hutan mangrove yang ada di Pantai Timur Provinsi Lampung. Nilai indeks SAVI provinsi lampung memiliki rentang nilai minimal antara -1 sampai nilai maksimal $1 ., 38$ Berdasarkan hasil analisis untuk objek mangrove memiliki rentang antara 0.26 1,38. Nilai indeks dijadikan sebagai acuan untuk penentuan kerapatan hutan pengolahan citra Sentinel menggunakan algoritma SAVI. Berikut merupakan hasil transformasi berdasarkan indeks SAVI. Berikut merupakan hasil transformasi berdasarkan indeks NDVI.

Penentukan kerapatan vegetasi yang dilakukan menggunakan algoritma NDWI, diperoleh nilai indeks NDWI provinsi lampung memiliki rentang nilai minimal antara $-0,99$ sampai nilai 
maksimal 1. Berdasarkan hasil analisis untuk objek mangrove memiliki rentang antara $0.24-47$. Nilai indeks dijadikan sebagai acuan untuk penentuan kerapatan hutan mangrove berdasarkan hasil transformasi algoritma NDWI.

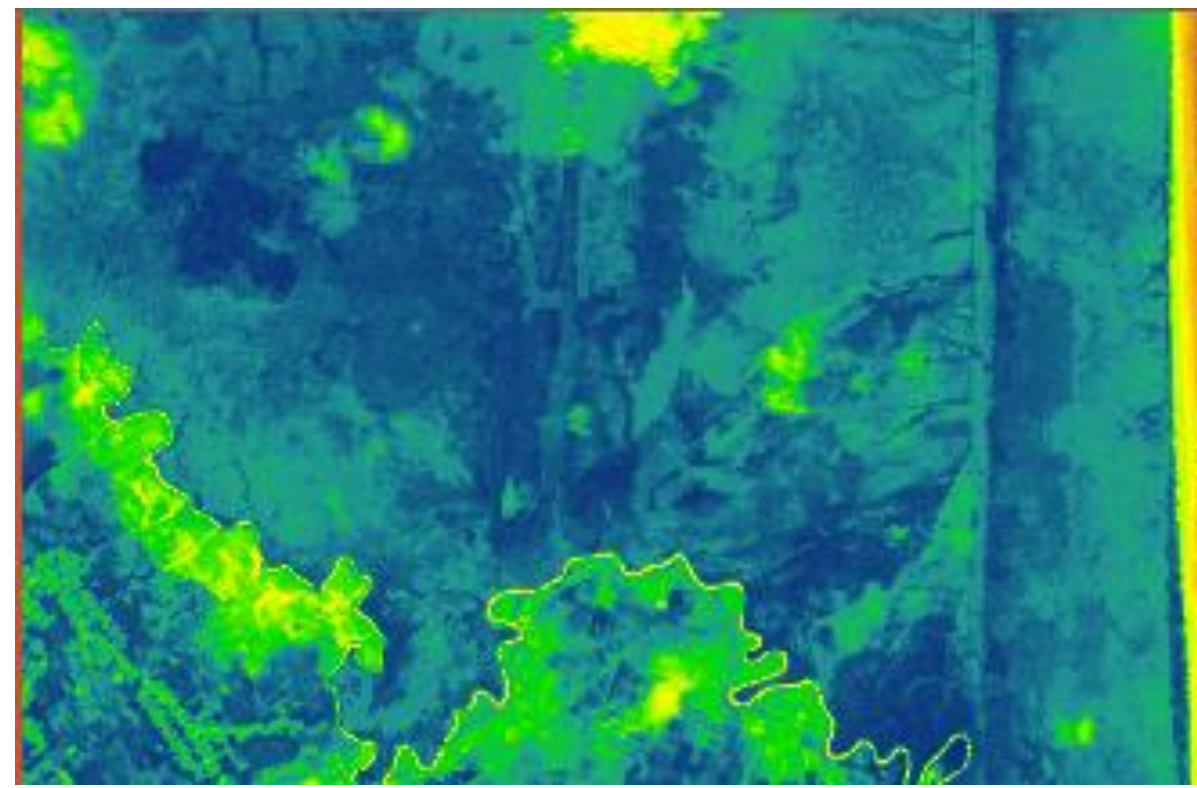

Gambar 6. tutupan mangrove berdasarkan SAVI

Berdasarkan hasil pengolahan NDWI. Berikut merupakan hasil citra Sentinel menggunakan algoritma transformasi berdasarkan indeks NDWI.

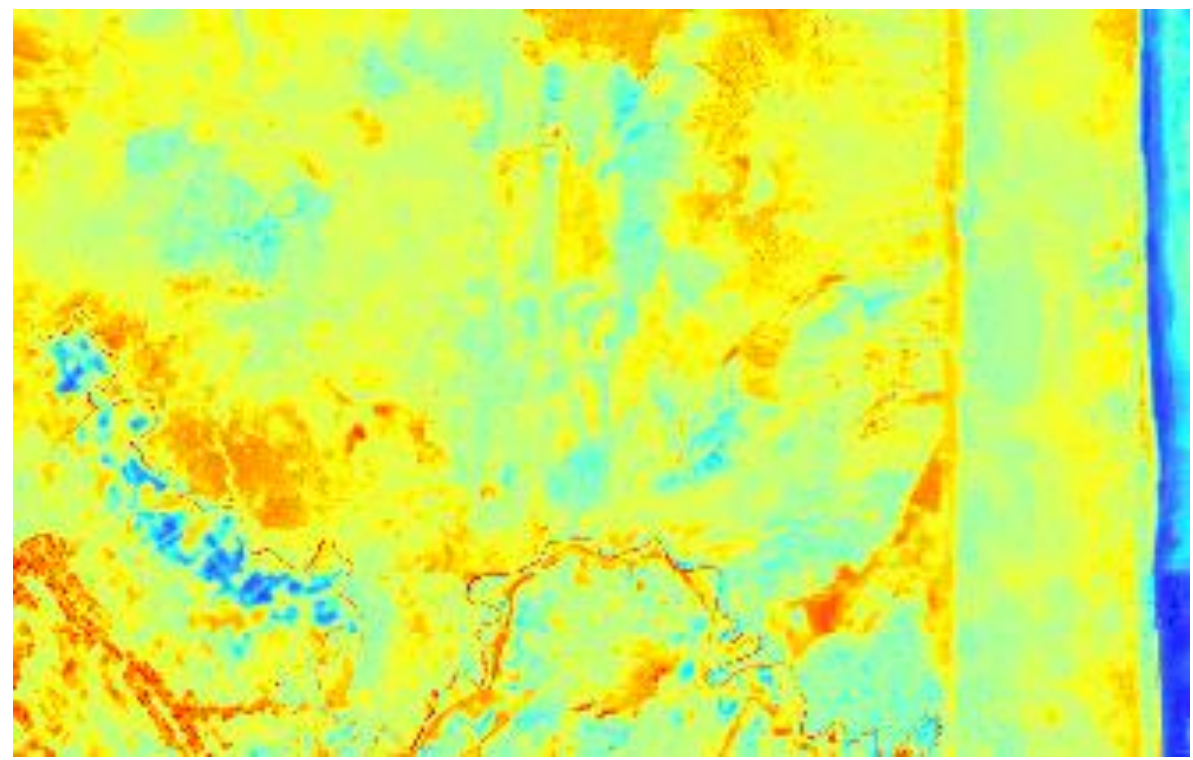

Gambar 7. tutupan mangrove berdasarkan NDWI

Analisis citra Sentinel pada pantai

timur Provinsi Lampung dilakukan dengan menggunakan algoritma indeks vegetasi. Dalam penelitian ini 
menggunakan tiga algoritma indeks yaitu NDVI (Normalized Difference Vegetation Index), SAVI (Soil Adjusted Vegetation Index), dan NDWI (Normalized Difference Water Index) untuk identifikasi kerapatan vegetasi pada transformasi NDVI didominasi kelas kerapatan tinggi yaitu pada rentang nilai 0,67 - 1 yaitu seluas 46975,96 Ha, pada transformasi SAVI didominasi kelas kerapatan sangat jarang yaitu pada rentang nilai 0,99 - 1,38 yaitu seluas 48775,18 Ha, pada transformasi NDWI didominasi kelas kerapatan rendah yaitu pada rentang nilai $0,1-0,17$ yaitu seluas 27442,26 Ha.

Berdasar hasil analisis dengan membandingkan antara nilai reflektans pada citra dengan hasil pengukuran dilapang menggunakan alat field spektrometer yaitu didapatkan standar deviasi pada indeks NDVI yaitu sebesar 0,188 dan standar deviasi pada indeks SAVI yaitu sebesar 0,28. Dari perbandingan hubungan antara indeks NDVI dan SAVI dapat disimpulkan bahwa algoritma yang memiliki hubungan paling besar dengan data hasil pengukuran dilapangan per area adalah algoritma NDVI dengan koefisien determinan sebesar 0,0258. Sedangkan nilai koefisien determinan SAVI sebesar 0,0221 .

\section{Akurasi dan Validasi Peta Kerapatan Vegetasi Mangrove}

Uji akurasi hasil klasifikasi kerapatan vegetasi mangrove bertujuan untuk mengetahui tingkat keakuratan hasil klasifikasi citra dengan kenyataan sebenarnya di lapangan. Lebih jelasnya disajikan pada Tabel 4.

Tabel 4 Uji Akurasi Peta Kerapatan Mangrove

\begin{tabular}{|c|c|c|c|c|c|c|c|}
\hline \multirow[t]{2}{*}{ Data Citra } & \multicolumn{7}{|c|}{ Data Lapangan } \\
\hline & $\begin{array}{l}\text { Tidak Ada } \\
\text { Vegetasi }\end{array}$ & Rendah & Sedang & $\begin{array}{l}\text { Agak } \\
\text { Tinggi }\end{array}$ & Tinggi & $\begin{array}{l}\text { Sangat } \\
\text { Tinggi }\end{array}$ & $\begin{array}{l}\text { User } \\
\text { Accuracy } \\
(\%)\end{array}$ \\
\hline Tidak Ada Vegetasi & 5 & 0 & 0 & 0 & 0 & 0 & 100 \\
\hline Rendah & 0 & 5 & 0 & 0 & 0 & 0 & 100 \\
\hline Sedang & 0 & 1 & 3 & 1 & 0 & 0 & 60 \\
\hline Agak Tinggi & 0 & 0 & 0 & 5 & 0 & 0 & 100 \\
\hline Tinggi & 0 & 0 & 2 & 0 & 3 & 0 & 60 \\
\hline Sangat Tinggi & 0 & 0 & 0 & 0 & 1 & 4 & 80 \\
\hline Total & 5 & 6 & 5 & 6 & 4 & 4 & \\
\hline $\begin{array}{l}\text { Producer Accuracy } \\
(\%)\end{array}$ & 100 & 83,33 & 60 & 83,33 & 75 & 100 & \\
\hline Overall Accuracy (\%) & 83,33 & & & & & & \\
\hline
\end{tabular}


Berdasarkan hasil uji akurasi yang dilakukan menggunakan 30 sampel uji diperoleh akurasi sebesar 83,33\% pada peta klasifikasi kerapatan hutan mangrove di Pesisir Pantai Timur Provinsi Lampung.

\section{KESIMPULAN}

Berdasarkan hasil analisis citra Sentinel dengan menggunakan transformasi indeks NDVI (Normalized Difference Vegetation Index), SAVI (Soil Adjusted Vegetation Index), dan NDWI (Normalized Difference Water Index) untuk identifikasi kerapatan vegetasi pada transformasi NDVI didominasi kelas kerapatan tinggi yaitu pada rentang nilai 0,67 - 1 yaitu seluas 46975,96 Ha, pada transformasi SAVI didominasi kelas kerapatan sangat jarang yaitu pada rentang nilai $0,99-1,38$ yaitu seluas 48775,18 Ha, pada transformasi NDWI didominasi kelas kerapatan rendah yaitu pada rentang nilai $0,1-0,17$ yaitu seluas 27442,26 Ha. Berdasarkan hasil uji akurasi yang dilakukan menggunakan 30 sampel uji diperoleh akurasi sebesar $83,33 \%$.

\section{DAFTAR PUSTAKA}

Danoedoro. P, 1996. Pengolahan Citra Digital, Teori dan Aplikasinya dalam Penginderaan Jauh. Fakultas Geografi Universitas Gadjah Mada, Yogyakarta. 253 hal

Faizal, Ahmad, and Muhammad Anshar Amran. "Model transformasi indeks vegetasi yang efektif untuk prediksi kerapatan mangrove Rhizophora mucronata." Metode 114.064 (2002).

Hartono. 1998. Penginderaan Jauh dan SIG untuk Vegetasi. Yogyakarta: PUSPICS, Fakultas. Geografi, Universitas Gadjah Mada bekerjasama dengan Bakosurtanal

Kustandiyo, H. (2014). Studi Tingkat Kerapatan Mangrove Menggunakan Indeks Vegetasi. Geoid - Journal of Geodesy and Geomatics. Vol 9, No 2 (2014)

D. R. Putri, A. Sukmono, and B. Sudarsono. (2018) "Analisis Kombinasi Citra Sentinel-1a Dan Citra Sentinel-2a Untuk Klasifikasi Tutupan Lahan (Studi Kasus: Kabupaten Demak, Jawa Tengah)," Jurnal Geodesi Undip, vol. 7, no. 2, pp. 85-96.

Riwayati (2014) 'Manfaat Dan Fungsi Hutan Mangrove Bagi Kehidupan', Jurnal Keluarga Sehat Sejahtera, 12(24).

Swain. P. H and Davis, S. M (ed)., 1978. Remote Sensing the Quantitative Approach. British Library Cataloguing in Publication Data, Mcgraw- Hill. New York. 395p

Wiweka, dkk. 2014. Pengembangan Model Identifikasi Daerah Tergenang (Inundated Area) Menggunakan Data Landsat-8. Jurnal Seminar Nasional Pengindraan Jauh. LAPAN. Bogor.

http://ksdae.menlhk.go.id/berita/594/kon ferensi-internasional-ekosistemmangrove-berkelanjutan.html. diakses pada tanggal 3 Maret 2020. 